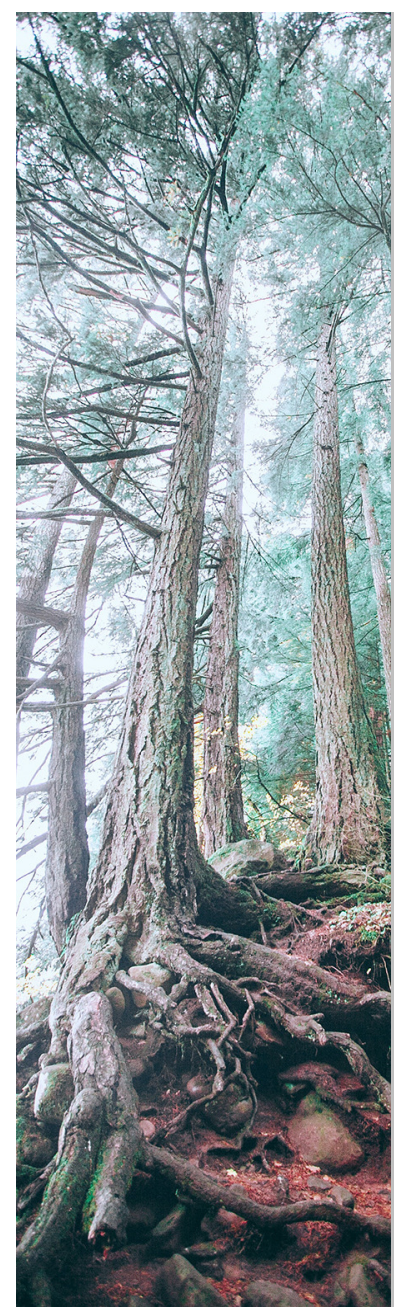

\title{
REFRAMING THE PROBLEM AND SOLUTIONS: TWELVE PERSPECTIVES FROM AROUND THE WORLD
}

\author{
Adrian Phillips ${ }^{1}$, Brent A. Mitchell1,2, Gilles Boeuf', Emily Bohobo N'dombaxe \\ Dola $^{4}$, Yolanda Kakabadse ${ }^{5}$, Ashok Khosla ${ }^{6}$, Richard Louv7, Freya Matthews ${ }^{8}$, \\ Elizabeth Maruma Mrema ${ }^{9}$, Mark Poznansky ${ }^{10}$, Fiona Reynolds ${ }^{11}$, Mary \\ Robinson ${ }^{12}$, Richard Roberts ${ }^{13}$, Juan Manuel Santos ${ }^{12}$ and Josefa Cariño \\ Tauli14
}

Corresponding authors: brentmitchell@qlf.org, adrian.phillips@gmx.com

${ }^{1}$ IUCN World Commission on Protected Areas

${ }^{2}$ QLF Atlantic Center for the Environment, USA

${ }^{3}$ Pierre-et-Marie-Curie University, Sorbonne University, France

${ }^{4}$ Youth4Nature

${ }^{5}$ Fundación Futuro Latinoamericano, Ecuador

${ }^{6}$ Development Alternatives, India

${ }^{7}$ Children \& Nature Network, USA

${ }^{8}$ La Trobe University, Australia

${ }^{9}$ Convention on Biological Diversity, Montréal, Canada

${ }^{10}$ Massachusetts General Hospital, USA

${ }^{11}$ Emmanuel College, Cambridge, UK

${ }^{12}$ The Elders

${ }^{13}$ New England Biolabs, USA

${ }^{14}$ Global Youth Biodiversity Network, Philippines

\section{ABSTRACT}

A dozen short essays in the form of personal reflections by distinguished people, the authors of which were all asked to consider the deeper implications of the pandemic and its significance for humanity's relationship with nature. The authors include former Presidents of two countries, two Nobel prize winners, two former Presidents of IUCN, several leading academics, and leaders of international conventions, national and international NGOs, Indigenous Peoples and global youth. Together, they cover every aspect of human endeavour from economics to ethics, and address the roles of the international community, governments, industry, civil society and individuals.

Key words: leadership, philosophy, humanity, vision, youth, inter-generational responsibility, nature, global

\section{INTRODUCTION}

When we put together this special issue, we decided to complement the peer-reviewed articles with a collection of voices of distinguished people who have been thinking about the deeper implications of the pandemic and its significance for humanity's relationship with nature.

We asked them all this question:

As we come out of the COVID-19 pandemic, how do you think our ideas about the place of nature in society will have changed and what might that mean for the development of more effective approaches to its conservation, and especially the role of protected areas?
We requested brief, 600-word answers to this question from environmental leaders and scientists around the world. As far as possible, we wanted personal reflections rather than institutional answers.

We were delighted by the responses we received and are grateful for the time and thought that busy people gave to this question. We reproduce their replies below between short bridging commentaries.

There were some clear common themes which came up time and again:

- COVID-19 has reminded us of humanity's dependence on nature. We need it, collectively and as individuals, for our happiness, well-being and survival. 


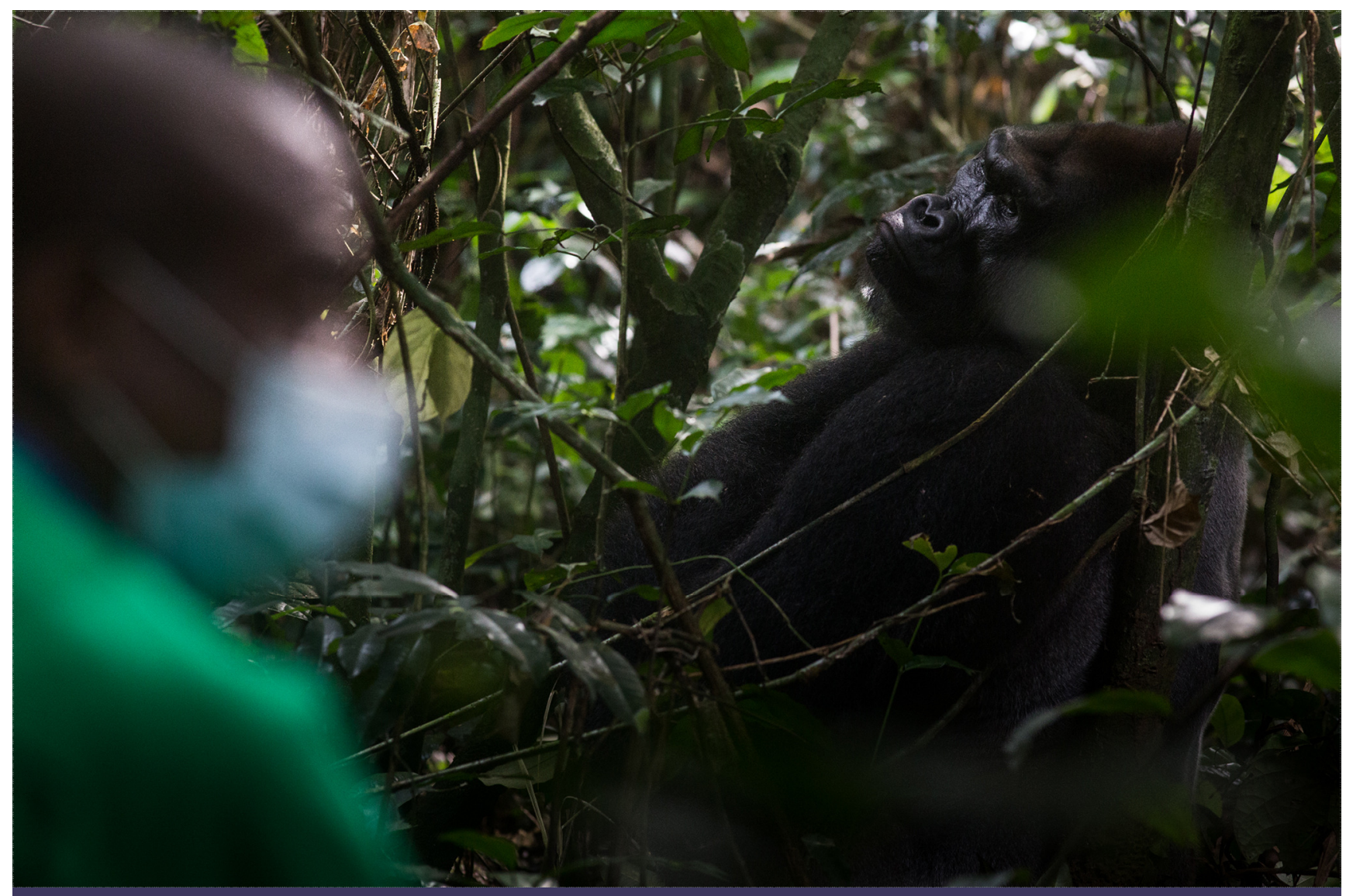

Humans are of course not the only species vulnerable to viruses. A silverback Western Lowland Gorilla known as Kingo. Nouabale-Ndoki National Park, Democratic Republic of Congo, near the border with the Central African Republic. @ Jerome Starkey

- The pandemic is a symptom of our disrupted relationship with nature: it occurs against the background of the only great extinction in our planetary history that has been caused by one species.

- The worldwide abuse of nature that led to the pandemic is paralleled and exacerbated by other alarming global, human-induced changes: climate change and pollution of air, land and water. All stem from the same cause: the excessive demands we make on the planet.

- While the pandemic has been a profound shock, it can also be a once-in-a generation opportunity to reset humanity's relationship with the natural world.

- To do so, we must learn the lessons of the pandemic - above all, the dangers of continuing along the current path of pillaging and destroying nature.

- We should also learn from our response to COVID19. We have shown that we can, with some difficulty, organise society - nationally and globally - for a common purpose.

- But 'Building Back Better' post-COVID cannot mean a return to 'Business as Usual'. Now is the time to address the root causes of our ills: many aspects of our economic system, our unsustainable exploitation of nature and the gross inequalities between peoples.

- All this calls for a spiritual and philosophical renaissance, in which we re-discover our individual and collective dependence on nature, and which puts nature at the heart of how we organise our economy and society in future.

- This is demanding but we have the necessary knowledge - from global plans and targets to Indigenous wisdom; from national conservation strategies to creating and managing protected and conserved areas. The challenge is to make use of what we know.

- If we use that wisdom, learn the lessons of COVID-19 
and act with our descendants in mind, we can make this awful pandemic a turning point towards a fairer, greener, more sustainable world.

Now let our guest writers speak for themselves. Adrian Phillips and Brent Mitchell

\section{Mary Robinson and Juan Manuel Santos are members of The Elders, a small group of "independent global leaders working together for peace and human rights". As two highly respected former Heads of State, they speak with authority and knowledge of what the world needs to do after COVID-19, and of what is possible.}

\begin{abstract}
Mary Robinson was the first woman president of Ireland, a former UN High Commissioner for Human Rights, and is chair of The Elders, an independent group of global leaders working together for peace, justice and human rights.
\end{abstract}

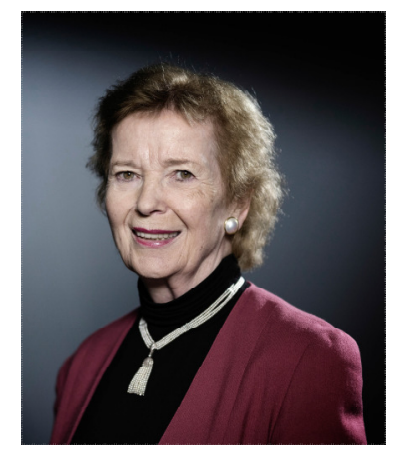

The COVID-19 crisis has created chaos leaving no nation untouched, but it has also taught us lessons. Compliance with social distancing measures has shown us the collective power of changes in our behaviour, when combined with responsible political leadership and effective systems of governance. Just as we can change our behaviour to protect the most vulnerable to a virus, we can also promote a paradigm shift to better protect nature and those most vulnerable to climate change.

The pandemic has underscored the close connections between people, nature and climate. Firstly, we know that to reduce the likelihood of future pandemics and zoonotic threats we must halt the rapid environmental decline we have seen in recent decades. Secondly, in our own lives, the pandemic has acted as a reminder of how completely dependent we all are on healthy and vibrant ecosystems for our well-being, for our medicines, our water and our food.

We have an opportunity to forge a new relationship with nature grounded in good governance, science and compassion. This new approach must recognise that efforts to tackle the climate crisis and biodiversity loss are inextricably linked. Protecting and restoring nature is also key to meeting climate goals, as the loss of biodiversity and extinction of species is one of the many layers of injustice created by the climate crisis. We already have a solid foundation for building back better. Both the 2030 Agenda for Sustainable Development and the Paris Accord should act as cornerstones of a green, healthy, resilient recovery.

In my role on the Global Steering Committee for the Campaign for Nature, I have joined a call on world leaders to protect at least 30 per cent of the planet's land and oceans by 2030. While the task of protecting these 'Green and Blue Belts' may seem daunting, the science tells us that this is the minimum effort needed to halt global biodiversity loss. However, the last decade has shown us that targets alone are not enough in the face of powerful economic interests driving the destruction of nature, particularly in the industrial agriculture sector. Just as important are the means of implementation to translate these into real-world change. The Science Based Targets initiative is developing a methodology for companies and cities to internalise environmental limits into their own operations, and set quantifiable, sciencebased, specific goals across their value chains. This is the kind of standard we need for companies and cities to be part of the solution.

As we consider our economic rescue plans in response to the emerging global recession, I believe now is a good time to ask: How can we make this target of 30 per cent tangible? How can we develop standards that governments, the private sector and others can work with? How do we protect nature while simultaneously protecting local communities who live in protected areas? How can we bolster the rights of local and Indigenous communities so they can continue protecting territories that they have been guardians of for generations?

For too long, we have seen ourselves as 'outside of nature'. This separation has become entrenched in every aspect of our lives, and our economic and political systems have been built on extraction at any cost. Indigenous people and many communities in the Global South have much to teach us about a different way of doing things. If we are to truly 'build back better' from the COVID-19 crisis, we must recognise it is only through our connection with nature, and one another, that we have hope of creating a safe, fair, liveable future for us all. This shift in thinking will be huge, but if we are to take some hope from the coronavirus pandemic, it is that we are capable of change. 


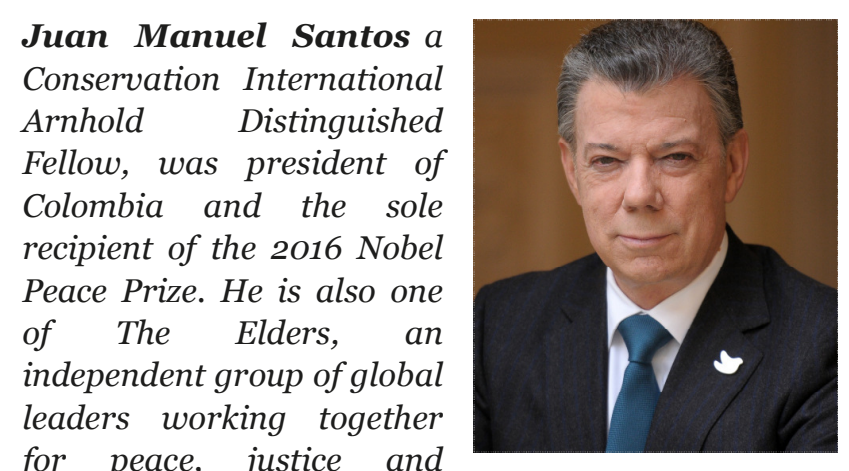
for peace, justice and human rights.

The current pandemic is remarkable not only for its economic shockwaves but for its impact in galvanising solidarity for 'green recoveries' and emerging recognition that our global economy relies on nature to thrive. Our world remains divided on how we deliver solutions to address global challenges. We are experiencing extraordinary strides forward, such as Europe's historic breakthrough with its ambitious Green Deal, as well as significant setbacks, with countries around the world rolling back environmental protections so that previously protected areas can be used for mining, drilling and accelerated deforestation.

Looking beyond the pandemic, our best hope of unifying all sectors of society and bringing nations together around areas of mutual interest lies in recognising the value of collaborative, science- and nature-based approaches to solving critical global threats. Protected and conserved areas are some of the most effective tools for conservation, and are crucial for sustaining plant and wildlife species, securing livelihoods and mitigating climate change. Well aware of this, we increased natural protected areas in Colombia from 13 million to 43 million hectares, equivalent to the area of Sweden.

As major economies assemble enormous economic packages to cushion the shock of the coronavirus pandemic, investors, politicians and businesses need to integrate the value of our relationship with nature into their decision making to save ourselves and the planet. Our well-being is dependent on healthy, vibrant ecosystems. My home country Colombia is the second most biodiverse nation in the world, but also one of the most vulnerable countries to climate change. In Latin America, the Amazon's Indigenous population is under siege from the impacts of the pandemic and increased deforestation and unprecedented fires that have destroyed massive areas of the world's largest rainforest. Not only has the pandemic taken countless lives, it has also crippled the livelihoods of people that rely on protected areas for income.
There is no pathway to a safe climate which does not also involve significant upscaling of nature-based solutions. According to the UN's biodiversity science body IPBES, global warming is the third biggest factor driving species extinction. And healthy ecosystems are vital in the Earth's ability to absorb CO2. It has been estimated that as much as 37 per cent of the costeffective carbon emissions reductions needed to meet the Paris Agreement can come from the natural climate solutions of stopping deforestation, restoring degraded lands and better managing the way we use land.

I believe these solutions are essential for a sustainable future, which is why we need to support and work with Indigenous peoples and other partners to expand adoption of natural climate solutions. The world's Indigenous peoples have been living in harmony with nature for centuries. They still sustain many of the healthiest ecosystems on Earth. Although today they make up only 5 per cent of the global population, Indigenous peoples effectively manage more than a quarter of all land on Earth and protect about 80 per cent of global biodiversity.

A true 'green recovery' cannot leave behind the communities connected to the very ecosystems we seek to protect. Together with fellow members of The Elders, I have been calling for the ratification of the Escazú Agreement, an historic treaty guaranteeing environmental rights for communities in Latin America and the Caribbean, and providing special protections for environmental human rights defenders.

In the wake of the COVID-19 pandemic, protected and conserved areas and the rights of Indigenous peoples must be at the heart of our future plans to build back better and restore a more sustainable global economy.

Elizabeth Maruma Mrema focuses on the role of the Convention on Biological Diversity, stressing the need for international action on lines that are already widely agreed. She appeals for global solidarity at this critical time.

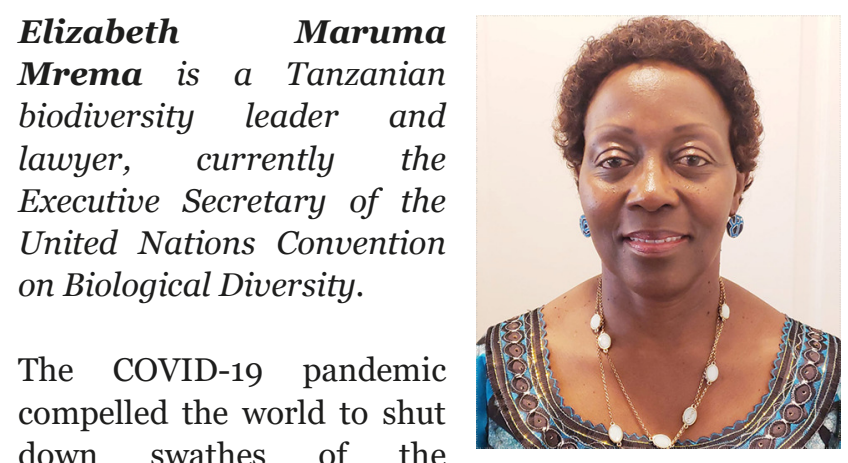


economy and has demonstrated that the foundations of prosperity are precarious. Disasters long talked about, and long ignored, can come upon us with no warning, turning life upside down and shaking all that seemed stable. The COVID-19 pandemic may have ushered in a new kind of war, which could confront humanity with a range of threats for many years yet. Responding to these will call for a more just global order and a determination to deliver far better outcomes for future generations.

One such threat is the biodiversity crisis. Extinction rates are estimated to be 1,000 times the background rate and future rates could soon become 10,000 times higher. In response, the Intergovernmental SciencePolicy Platform on Biodiversity and Ecosystem Services (IPBES) recently launched its 'Global Biodiversity Outlook 5' report. It describes how biodiversity loss, compounded by land degradation, desertification and climate change, now threaten life on Earth in an unprecedented way. These forces reinforce each other. Unless this vicious circle is broken, they will undermine all efforts towards sustainable development and create a dark future for humanity.

In the face of this challenge, the Post-2020 Global Biodiversity Framework is our road map and its implementation a necessity for our survival. The next 10 years will be the most critical of our generation. Without much more determined action, nature will be destroyed on an appalling scale, with ever greater environmental threats and climate-related impacts, including floods, storms, drought, desertification, food shortages, water scarcities, wildfires, sea level rise and depletion of the oceans. To avoid this nightmare future and realise instead the 2050 Vision of Living in Harmony with Nature, the nations of the world must deliver on the 2030 Agenda for Sustainable Development.

The Parties to the Convention on Biological Diversity recognise that protected and conserved areas are cornerstones of biodiversity conservation. They constitute important stocks of natural, cultural and social capital and yield economically valuable goods and services that benefit human populations. If they are to function well, they must be effectively managed and governed with inclusiveness, transparency and equity, and encourage the participation of Indigenous peoples and local communities, and youth, among others.

There is some good news. We are on track to exceed Aichi Target 11 - of 17 per cent of terrestrial areas under protection, and 10 per cent of marine and coastal waters. Almost 20 million $\mathrm{km} 2$ in protected land and sea areas have been added over the last decade. With coherent and concerted effort, globally agreed targets can be achieved.

The COVID-19 pandemic taught us that by working together and in solidarity, we can end the pandemic, tackle its consequences and build resilience against future pandemics. We should transfer that lesson to the challenge of biodiversity by implementing the Post2020 Global Biodiversity Framework. Moving into the post-2020 period, we will need increased ambition and implementation, as well as a greater focus on protected area quality. By leading humanity away from its current destructive course, we can achieve the 2050 Vision of Living in Harmony with Nature. But that will require a concerted effort from all stakeholders: governments; global, regional and sub-regional organisations; nongovernmental organisations, civil society, the private sector, academia and others. If we take one message from COVID-19, it is this: we are all in this together. So, let's all resolve to implement the Post-2020 Global Biodiversity Framework and the 2030 Agenda for Sustainable Development in full and on time. There is no alternative.

As former presidents of IUCN, Yolanda Kakabadse and Ashok Khosla both bring a lifetime of high level experience of international environmental politics. Both are concerned that our relationship with nature urgently needs repair. Unless we act soon, address the faults in the global economic system and begin to value nature properly, the future for both people and nature will be dark indeed.

Yolanda Kakabadse is a
former president of both
IUCN and WWF-
International, and Ecuador's
former minister of the
environment.

Pandemics shed light on the fragility of social structures created by human societies to function and interact in

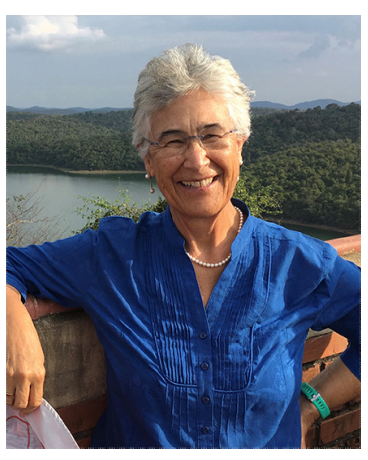
national, regional or global spaces. Pandemics provide evidence of the risks we must face when the links between nature and we humans are broken to prioritise economic or political wins, when the value of biodiversity is not recognised, when protected areas are not considered as a savings account of humanity.

While the coronavirus has brought a great deal of harm to global and national economies, and to the most 
vulnerable sectors of society, it has certainly given us the time to reflect on the links between this crisis and nature, the environment and the natural resources on which life depends. These links have always been there, but we have not done much to recognise their importance.

The direct relationship between the health of humanity and of nature, and the value of this relationship, have not been properly incorporated in economic analyses and projections of human development, nor have they been given the necessary weight in the planning of sustainable development. We have the opportunity now to review this approach and build something different, where nature and especially protected areas are at the centre. The stability of nature is our long-term insurance policy and protected areas are an important part of the balance between humanity's growing needs and desires and the capacity of the planet to meet them. In many parts of the world, protected areas have not been more than lines on a map, and often regarded only as an obstacle to conventional development. The COVID -19 crisis is the perfect opportunity to re-evaluate their importance and recognise the need to invest in programmes that guarantee their integrity. But that will not happen unless they are explored and enjoyed by the common citizen. That's our challenge now: to invest much more in familiarising citizens with the values of nature and the importance of keeping exceptional areas as reserves. We will only protect what we know, understand and care about. The importance of nature and its services to humanity are suddenly a conversation topic, a theme as important as health or job creation. They are being discussed by decision makers and not only by the conservation community. This decade must rescue and strengthen the concept of solidarity: between us and nature, between generations, between countries, between peoples. The discussion has started; it must continue.

\section{Ashok Khosla is the chair of Development Alternatives and former co-chair of the United Nations Environment Programme's International Resource Panel (UNEP-IRP), and a former president of both IUCN and the Club of Rome.}

The first priority facing the

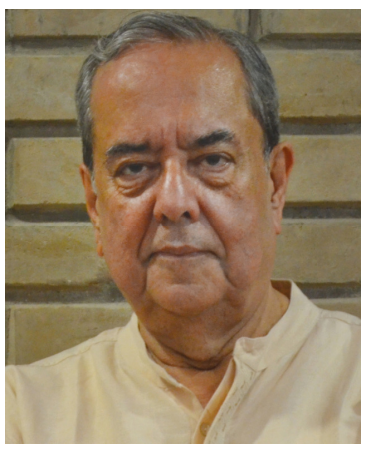
world today must undoubtedly be to place the wellbeing of people and the productivity of nature, now and for the future, at the core of post-COVID-19 economic recovery plans. This is the quickest and surest way to revive the health of our fellow citizens, speed revitalisation of our economies and accelerate the creation of jobs. It will also rebuild the resilience of our economies, ecosystems and institutions to cope more effectively with such emergencies - and prevent them in the future.

Beyond the current COVID-19 pandemic, our world faces many even deeper, more intractable and persistent crises, rooted in a number of interconnected global challenges. Some are manifested locally, such as pervasive poverty and marginalisation, pollution, land use change, and species and habitat loss; others are national or regional, such as deforestation, human and wildlife trafficking, unsustainable trade practices and resource depletion; and some are global, like threats to the climate, biodiversity and oceans - and collapsing international financial and trading systems.

We now understand that the pandemic, along with these other challenges, results from the lopsided value systems and institutional arrangements that underlie our current economic policies and practices. Events like the Dotcom bubble of 2000, the Sub-Prime Mortgage meltdown of 2008 and the current Coronavirus contagion are just the triggers, the proximate causes of our economic crises - the ultimate causes lie hidden from today's governance institutions by the false promises of neo-classical economics and neo-liberal economic policies. If, post-pandemic, these remain and we return to 'business as usual', the world cannot achieve the levels of social justice, resource efficiency and environmental health that all nations say they aspire to.

As most of these threats transcend national or physical borders, international cooperation and a new kind of global solidarity are essential to restore the balance between people and nature and to build future resilience to the existential threats that we will face with increasing regularity and force. Strong new institutional networks and nodal agencies need to be built up at the regional and national levels to act as bridges between global entities such as the UN, WHO, FAO, Red Cross/ Red Crescent, etc., and local institutions working on the ground and on the front line.

The dreaded virus gives us a cruel but serendipitous and critically needed opportunity to press the button to reset the system. Governments, business and civil society must respond by fulfilling their national and global commitments to maximise social and economic equity, minimise greenhouse gas emissions, conserve 
biodiversity, raise resource efficiency and reduce wastes and pollution. We know what needs to be done: we now need to introduce serious policies and practices to replace fossil fuels with renewable energy; protect nature and restore our forests, rivers and degraded lands; and adopt nature-based solutions to replace mechanised, resource-guzzling ones.

Investments in eradicating poverty - and thus completing the demographic transition to a stable world population - and building the resilience of ecosystems that deliver among the highest returns to the economy, now and in the future, are also the lowest cost means for preventing future disasters, natural or manmade. As the recent report on the 'Future of Nature and Business' from the World Economic Forum shows, there is a very strong business and economic case for taking a proactive, bottom-up, systemic approach to addressing such planetary emergencies.

Above all, we must secure the future of our food, water, energy and soil supplies and meet the basic needs of all. We need to: create safe and sustainable food systems by adopting regenerative agriculture; decentralise and revitalise local production systems; and shift to a more inclusive, green and circular economy. Most important of all, we need to protect, regenerate and conserve biodiversity and ecosystem services which are now under greater threat than at any time since an asteroid hit the Earth some 65 million years ago.

E.O. Wilson's call for protecting half the Earth from human predation may not be easy to achieve but it dramatically underlines the gravity of our collective predicament and the urgent need to expand our natural and wilderness areas.

Josefa Cariño Tauli brings an Indigenous perspective. She reminds us that in many places the conservation of nature depends on using Indigenous knowledge and that a pre-requisite is the recognition of Indigenous people's rights.

\footnotetext{
Josefa Cariño Tauli is an Ibaloi-Kankanaey Igorot Indigenous youth from the Cordillera Region in the Philippines. She serves on the Steering Committee of the Global Youth Biodiversity Network (GYBN), the official youth constituency to the UN Convention on Biological Diversity (CBD).
}

The pandemic presents society with a grim and unprecedented crisis. It is a crisis that affects everyone, yet the hardest hit are once again the poor and those who bear the brunt of structural inequality, including Indigenous peoples, children and youth, and women. We see the failings of the unjust systems that have brought us to this situation. But we also see that a massive mobilisation of capacity and resources to solve a pressing global crisis is possible - and we demand that the same effort be urgently extended to fight the looming ecological collapse, for the sake of future generations.

To learn from this pandemic, we must become acutely aware of connectedness: of our connectedness with all other people and places; of the links between past generations and ourselves, and our place as future ancestors to the coming generations; and of the quality of our own connections with nature. We also need to be aware of the inextricable links among the problems we face today: from biodiversity loss and climate breakdown, to inequality and the infringement of human rights, to the loss of cultural diversity and diverse knowledge systems. Thinking in silos is hindering us from addressing the root causes of these crises, with young people shouldering many of the longterm consequences.

Fundamental to building back to a more sustainable world is rebuilding lost connections with nature. Nature thrives where these connections remain strong - and such has been the case in many Indigenous peoples' territories around the world, despite the continuing and often targeted attacks against them. We must shift the conservation paradigm to recognise this and learn from it.

State-recognised protected areas have played a significant role in shaping society's perception of, and relationship with nature. Many people continue to look at protected areas as fortresses-protecting nature from the destructive force that is humanity. Thus, in many parts of the world, they are established, governed and managed in a strict, authoritarian manner, forcefully displacing communities who live within nature in the name of keeping biodiversity-rich areas 'pristine'. This has contributed to the breakdown of people's relationship with nature: rather than seeing ourselves as part of nature with the responsibility to care for our entire home and the basis of our survival and well-being, many have begun to think that, as long as we keep people away from certain beautiful areas, we can keep on wilfully yet blindly exploiting the rest of the Earth. 
Moving forward, we must then take steps to completely cut ties with the colonial and oppressive history of protected areas - towards an area-based conservation that is socially and politically feasible and morally just. First and foremost, we must secure the rights of Indigenous peoples to their collective territories, better enabling them to govern these areas on their own terms through Indigenous and local knowledge, practices and innovations. We must support and stand alongside them in their defence of these territories of life against external threats and destructive industries. We must build legitimacy for a new kind of protected area by proving that it is possible for them to be established and managed in ways that put human rights at the centre, including self-determination and free, prior and informed consent. And we must correct historical wrongs, establishing grievance and accountability measures for past instances of violations such as displacement and territorial capture in the name of conservation.

Indigenous peoples and local communities have the wisdom and knowledge to lead us towards a better path. Mainstream societies who have lost sight of humanity's inherent connections with nature must listen to and learn from them.

Fiona Reynolds offers an essentially national perspective. She reminds us that it is at the national level that action is often most critical and where nature must not only be defended but given scope to expand.

\section{Dame Fiona Reynolds is Master of Emmanuel College, Cambridge, United Kingdom, and is a former Director-General of the National Trust.}

If we ever questioned the dependence of the human spirit on nature, fresh air and beauty, the coronavirus

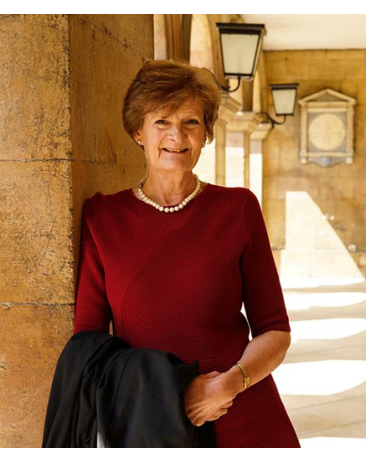
crisis has surely laid an end to it. The sight of people flooding to their local parks, National Parks, tourist hotspots and beaches in one of the sunniest summers on record, in spite of COVID-19 restrictions, sent a clear message. We need fresh air, we need to get outdoors and close to nature, and we'll do almost anything to achieve it.

At a time when many of us were forced to be still, we saw nature in all its glory: perhaps properly for the first time. We watched the first spring flowers unfurl, heard birds sing in the unnatural quiet of an aeroplane-free sky, and because we were advised to take exercise regularly, we exposed ourselves to the fascinating minutiae of daily changes in our surroundings. It made many of us really appreciate nature, close up.

There were downsides too, as we know. Sadly many National Park and local authority rangers had to deal with the pressures caused by mass invasions of beauty spots, littering (and worse), and the casual abandonment of tents and camping gear as if these were festival sites in the worst throw-away society. Yet for many people, unable or unwilling to risk a holiday abroad, this was their first experience of holidaying at home, and it would be wrong to condemn everything about this burst of enthusiasm for the beauty of Britain.

Indeed the Glover Review of protected landscapes in England (which reported in September 2019, and on which I sat) argued specifically that we must ensure that more people in Britain get to experience these extraordinary, beautiful places. We have designated 20 per cent of England as either National Parks or Areas of Outstanding Natural Beauty (AONBs) and they are rightly popular, but millions of people from poorer and ethnic minority backgrounds have never been to one. Indeed many have never visited the countryside at all.

We made our recommendations alongside an urgent plea for protected landscapes also to play a stronger role in nature recovery. Since around the 1950s, we have presided over a catastrophic decline in nature, exploiting it faster than its capacity to regenerate, and failing utterly to value the fundamental contribution it makes to our lives and collective future.

Shockingly nature has fared no better within protected landscapes than the wider countryside, yet these are areas where conservation is already a stated objective, where farmers and landowners are primed to play their part, and where authorities exist to support a proactive nature recovery programme, alongside well managed public access to these special places.

Imagine a fifth of England - the whole family of National Parks and AONBs - dedicated to nature recovery, leading the charge in restoring and connecting fragmented habitats; restoring peatland, wetlands, meadows and grassland; and creating new habitats by planting trees, letting field boundaries burgeon and slowing the flow of rivers. Along with land already under nature protection, that would help our country meet the 30 per cent international target for biodiversity conservation already proposed in the draft Post-2020 
Global Biodiversity Framework and accepted by the UK Government.

COVID-19 has given us an unprecedented opportunity to put things right. As David Attenborough has said, we only protect what we care about and only care about what we have experienced. Now we have experienced nature, it's time to prioritise the health of our planet alongside that of our people. To establish new norms to ensure we live within our environmental means, to safeguard nature and stabilise the climate, alongside measures to ensure social and economic well-being for all.

There's never been a better time to re-set our priorities and reverse nature's decline. Because not only do we, as people, need nature; but nature needs us: to value and restore it, for its own and our collective benefit.

Mark Poznansky and Rich Roberts are respectively an immunologist and a molecular biologist. Impressed as they are by the rapid production of successful vaccines to counter the spread of COVID-19, they believe that an even greater achievement would be the avoidance of many future pandemics altogether through the effective protection of nature.

Mark Poznansky is Director of the Vaccine and Immunotherapy Center and Attending Physician in Infectious Diseases Medicine at Massachusetts General Hospital directly involved in the acute care of patients with COVID-19 infection. He is also the Steve and Debbie Gorlin MGH Research

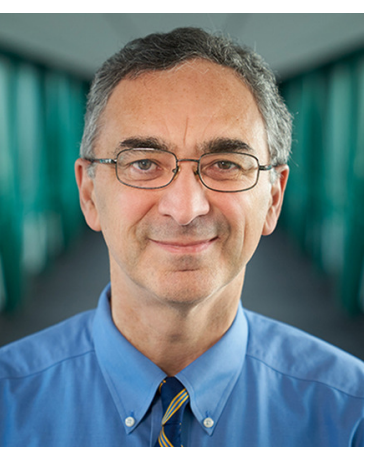

Scholar at MGH and an Associate Professor of Medicine at Harvard Medical School.

Sir Richard Roberts is Chief Scientific Officer at New England Biolabs, a world leader in the discovery and production of enzymes for molecular biology. Rich was awarded the Nobel Prize in Physiology or Medicine in 1993 for his contribution to the discovery of introns in eukaryotic DNA and the mechanism of gene-splicing.
It seems as if our human species must constantly learn the same lesson over and over again - that human life on planet Earth is inextricably linked with nature and the multitude of animal and plant species that live with us and amongst us in ways that both support and occasionally threaten our survival as a species. Nature nurtures us through its marvellous ecosystems, which support life on the planet, provide us with food and help stabilise the climate. However, nature can also threaten us, as when pathogens that thrive in animal species cross over and cause potentially deadly human infections.

It is likely that the COVID-19 outbreak resulted from markets in which wild animals were bought and sold to large numbers of people in Wuhan, China. We have been aware for decades of the dangers that arise when people live next to wild animals from which viruses can be transmitted. That threat has grown with expanding human populations and greater interference with natural environments.

People are coming to understand the climatic changes caused by the devastation of rainforests and the consequences of mining and burning fossil fuels without limit. Unless we also learn to protect and preserve the natural world that exists alongside us, we face the daunting prospect of a 'pandemic century' where manmade encroachments into the natural world leads to ever more transmission of pathogens from animals to humans.

Usually, when we invent a process that leads to problems, we invent something new to address the problem - when the wheel turns too fast and the object it carries runs out of control, we develop brakes, safety belts and a steering wheel. When fire burns out of control, we invent fire extinguishers and fireproof materials. Inventions beget further inventions. In the case of infectious diseases, the traditional response has been to isolate diseased individuals and - more recently - to make vaccines, which we are now doing with impressive speed. This is a natural human response that is good. But it avoids looking for solutions that address the root cause of the problem.

That is where we, an immunologist and a molecular biologist, believe we find ourselves. The greatest and most impactful healthcare measure - the vaccine - is still only one part of the solution. A vaccine is useful once a pandemic is growing - or, in the case of COVID19, raging. Safe and effective vaccines prevent the spread of disease, but do not eradicate the source of it. We need also to take the preventative measures to protect, nurture and preserve our natural environment wherever 
possible, and limit the ever-expanding interaction between humans and animals that provokes the transmission of pandemic infections. The old adage applies: "an ounce of prevention is worth a pound of a cure". If civilisation is to avoid a pandemic century, we must educate the public and politicians about zoonoses and act quickly to eliminate the risks inherent in the destruction of natural habitats.

Gilles Boeuf, Richard Louv and Freya Mathews - three thinkers who argue that COVID-19 challenges us to think anew about humanity's often damaged relationship with nature approach this topic from, respectively, biological, philosophical and spiritual standpoints. Theirs is a moving call for us to reawaken our respect for the natural world, upon whose health our own health depends.

Gilles Boeuf, a
distinguished French
biologist, is a Professor at
Pierre-et-Marie-Curie
University, Sorbonne
University and former
president of the French
National Museum of
Natural History.

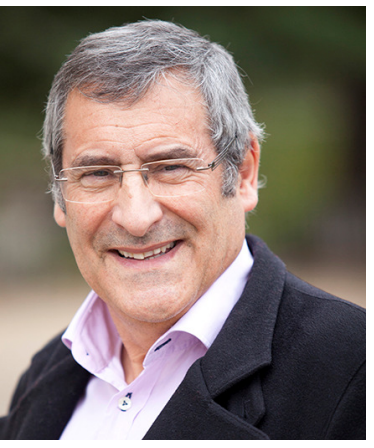

We are not at war against a virus, but against our own failings, our own actions, our own irresponsibility towards the planet. We are, after all, our own enemy. This is due to our culpable servility to dogmas - liberal economics, growth, consumption, property, hurry, and of course profit - in the name of which humanity, blinded by its anthropocentric arrogance, believes itself authorised and even incited to overexploit 'nature' capital to the point of its annihilation. When will there be a real questioning: a sense of what one initiates, builds, spreads; of what one creates, undertakes, shares? And precisely, what should we 'do with' this nature? Or, rather than 'doing with', what can we 'do with respect for' this biodiversity that is now in danger? What can we 'do while being inspired by' this wonder of living species, animals and plants, to which humans belong - humans, who, in their scientific intoxication, believe they possess it? What 'to do', in the end, so that humans' relationship with nature, humans' consideration for nature, no longer cements humanity in the suicide it has programmed, and interrupts the progression of ecocide?
In this period of lockdown and reflection that favours introspection, everyone can rethink the way they interact with other species, their relationships with living things, and the impact of their daily actions on the future. To prepare for the 'day after', let us draw inspiration from living things. When it is sufficiently preserved and in good condition, the diversity of living things amazes us, nourishes us, heals us, maintains us, reassures us, inspires us. In good condition - hence the value of protected areas - it protects us against pathogens (when biodiversity is present, it protects us against pathogens by a 'dilution' effect) and resists the encroachment of invasive plants. How can we escape from this myopia of disaster? Ecologists and epidemiologists have been warning of these possible pandemics since 2003. And it will come back if we continue as before. The acceleration of climate change is acutely challenging our behaviour. March 2020 was the hottest March in 160 years, and the heat waves will follow one another. This COVID-19 crisis is indeed linked to the mistreatment of biodiversity!

So today we have a short window of opportunity to overcome the challenges of the current crisis and avoid sowing the seeds of future ones. Will we be able to take advantage of it? When will we see the end of these markets for living animals in filthy conditions in Asia, an end to the unbridled extirpation of trees and animals in all the world's ecosystems, including tropical forests, and an end to constantly and systematically flouting the thresholds of renewability of life on land and at sea? An end to the perpetual wasting and polluting of water. An end to the 'ecological wheel' that transports everything everywhere, triggering explosions of invasive species and anarchic releases of pathogens of all kinds, viruses and bacteria, responsible for pandemics and so much suffering?

We even need to care, quite viscerally, for the biodiversity within our own bodies - micro biota - since the virus targets people already weakened by a bad relationship between their human cells and symbiotic microbes.

We are biodiversity. We consume it for our food and must cooperate with it for our survival! Yet we constantly forget our dependence on nature. Therefore, let's not go back to the system of an unbridled economy that aims to build a profit on the destruction or overexploitation of our capital: nature and biodiversity. Let us always remember: we are water, salts and cells! Can a small virus composed of only fifteen genes cause the collective electroshock we need? 
Richard Louv is the author of 'Last Child in the Woods: Saving Our Children from NatureDeficit Disorder', 'Our Wild Calling', 'The Nature Principle', 'Vitamin $N$ ' and other books. He is chair emeritus of the Children \& Nature Network.

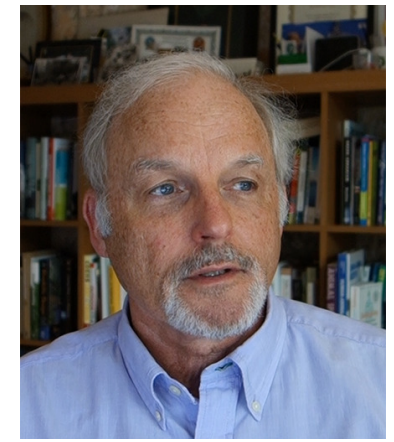

Last year, during Australia's devastating fires, many of us were moved by the images of scorched forests and suffering animals. We watched burned koalas climb onto human laps to reach bottles of water held by people who had lost their own home. They had headed out "with only the clothes on their backs to help injured and burned animals", as an NGO reported.

These images reminded us that we belong to a larger family of animals.

What will it take to move our species to act on the environmental challenges of our time? Science is essential. But data alone will never sufficiently move hearts and minds. We must muster the power of two additional forces. One element is love, a deep emotional attachment to the nature around us. The second is hope - not blind hope, but imaginative hope.

The Australian eco-philosopher Glenn Albrecht argues that only "a shift in the baseline of emotions and values has worked" to transform facts into action in other movements, including feminism, samesex marriage and racial inequities. Each of these causes revolved around the power of relationship. And love.

Human loneliness now ranks with obesity and smoking as an indicator of early death. The breakdown of the extended family, unwalkable cities, anti-social media and the dominance of screens - these are among the reasons for the parallel pandemic of human isolation. But I believe the rise of human loneliness is rooted in something older, deeper - our species loneliness.

We humans are desperate to feel that we are not alone in the universe. And yet, we are surrounded by a great conversation that unites us with other species. If we pay attention.

Today, an expanding body of research suggests that a direct bond with the natural world is fundamental to emotional, physical, cognitive and social health. Partly as a result of that research, a new nature movement has emerged, one that works to connect children, families and communities to the natural world. A growing number of paediatricians are now writing prescriptions for nature time. Biophilic architects are weaving natural elements into workplaces - for aesthetics, but also for increased productivity and reduced sick time.

What if whole cities could be transformed through biophilic design?

As policymakers draw blueprints for a pandemic-altered future, they should envision communities with equitable distribution of parks, wildlife corridors and natural schoolyards, with room for social distancing.

Hope is more realistic if we view climate disruption, biodiversity collapse, zoonotic pandemics and human isolation as a single existential threat with shared solutions. The seeding of vast new multi-species forests and other wildlands could reduce the rate of biodiversity collapse, absorb a substantial amount of $\mathrm{CO} 2$, help slow or reduce global warming and improve human wellbeing. Our species can thrive only if we attend to the health of wildlife and the planet. This is the guiding principle of a public health approach called One Health.

As part of an enlarged environmentalism, positive nature connection should be recognised for what it is: a human right. In 2012, the IUCN World Conservation Congress passed a pioneering resolution called 'The Child's Right to Connect with Nature and to a Healthy Environment'. For people of all ages, full acknowledgement of that right will require an additional recognition of the rights of nature.

The children of all species may yet live in a nature-rich future, but only if people and countries galvanise the full powers of science, love and imaginative hope.

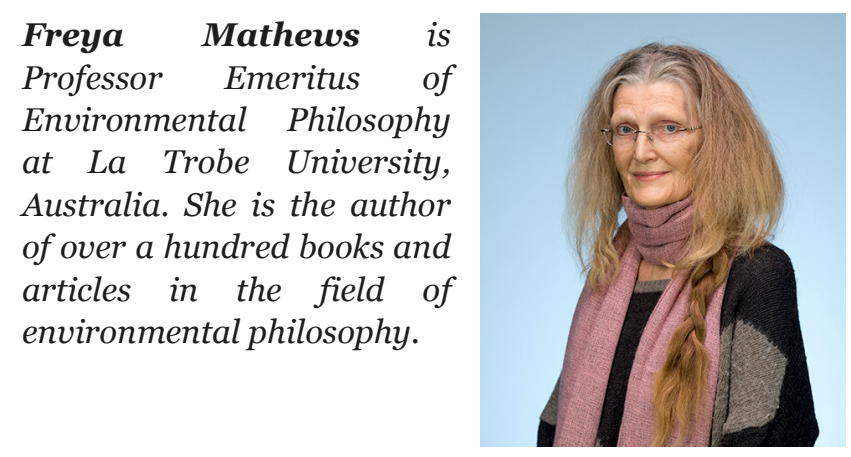

With ecological catastrophe now on a continental scale witness fires in the Arctic, Amazon, Australia and the American West - and the global spread of COVID-19, humanity faces a future in which the certainties that have undergirded civilisation are crumbling. 
To respond to this epochal shift, we will need to convert civilisation itself from biosphere-antagonist to agent of biosphere self-repair. We must create an ecological civilisation: one imbued with ecological consciousness and economically organised around forms of material production and consumption that enhance the richness and diversity of the biosphere.

Different cultures will understand and articulate ecological consciousness in different ways. In Western societies, such consciousness will involve repudiation of the old mechanistic premises of modern industrial civilisation and rest instead on affirmation, in new, scientifically literate ways, of the irreducible agency of living systems, including that of the Earth-system as a whole. As a self-realising system in its own right, organised in such a way as to preserve and increase its own integrity, the biosphere may be seen as embodying self-purpose and self-value. Its integrity is never assured but must be continuously adjusted and renewed via the system's own efforts. When the components of the system all play their own distinctive parts in its ongoing self-configuration, the system flourishes. If some of them fail to do so - or if the system is subject to external impacts to which it is not adapted - then its integrity may be impaired: the system may fall ill, as is currently the case.

The pandemic has taught us, in a way that the prospect of a sixth great extinction event evidently did not, that we ourselves inevitably become embroiled in global processes of ecological dis-integration: such processes not only render the planet progressively uninhabitable but can end up infiltrating the very tissue of our bodies. The COVID-19 virus has revealed that our individual identity as organisms is more attenuated than we perhaps realised. Life on Earth might now appear not merely as a jigsaw of intersecting, co-conforming parts but as an actual 'plasma', a pattern of flows and interflows of living particles in which larger life forms configure themselves as only superficially distinct and stable eddies. Viewed from this perspective, the biosphere presents not merely in relational terms, as a systemic unity in whose webwork we are inextricably enmeshed, but also in such plasmic terms, as a higher order Body or, as ecophilosopher Arne Naess puts it, a larger Self.

Our own telos, as members of an ecological civilisation, will be to discover and then play our distinctive speciesrole in assuring the ongoing unfolding and flourishing of this larger Earth-Self. This will require adherence to core ecological principles of reciprocal accommodation

or biosynergy in every aspect of our lives, including every aspect of our productive praxis. Ecology as an axis for civilisation is in this sense normative: as members of an ecological civilization, we will share a core purpose and a common template for meaning, beyond the contingencies of our various historical cultures and religions.

The Earth-guided process of biosphere self-repair will require protection of all those areas in which the myriad micro- and macro-agents and catalysts of biosphere metabolism remain active. These protected areas are the repositories of information, the 'increase sites', to use the idiom of Aboriginal Australia, from which biosphere integrity can begin to be recovered: within these increase sites, Earth can begin the process of its selfreconstitution. One of our first steps towards ecological civilisation will accordingly be to expand these areas as much as we can, encouraged by the Half-Earth goal that E.O. Wilson has dared to set.

Creating ecological civilisation will be an inter-cultural endeavour drawing on deep cultural synergies across societies. It will articulate itself differently in different parts of the world but converge around this idea: that our purpose, as humans, is to contribute to the ongoing unfolding and flourishing of the living Earth, our larger Self.

Finally, the voice of the next generation. In her 'Urgent Message from Youth', Emily Bohobo N'Dombaxe Dola sets down a challenge to the decision makers of today. Her "tenacious generation" of young people are, she says, committed to fighting for success in both the climate and nature arenas - but asks whether world leaders are ready too.

\section{Emily Bohobo N'Dombaxe \\ Dola is the Storytelling Programme Director at Youth4Nature and a member of the global youth climate- nature movement, focused on agri-food systems, adaptation and resilience, and social/ economic justice.}

In 2019, young people were instrumental in bringing climate and environmental issues to the forefront of international and national politics. From youth-led climate strike marches and online mobilisation efforts to 
a visible and vocal presence at key agenda-setting events, the message from young activists and organisers in 2019 was clear: we need to act now, not only to avoid a menacing future, but also because of existing threats to lives and livelihoods. And we owe it to Planet Earth to put right the harms we have committed in the past.

The voice of youth in 2019 emerged at the same time as nature was being mainstreamed as a solution to climate change. Silos were at last broken down as politicians and organisations acknowledged the importance of integrating climate action with biodiversity action, and with broader work around social and human well-being challenges. By the end of 2019, the 'climate-nature' movement had seemingly gained an unstoppable momentum. The next step was to seize the decisionmaking opportunities presented by the '2020 Super Year for Nature' by acting on the reports from the IPBES and the IPCC.

Little did we know then that the COVID-19 pandemic would dramatically highlight the interplay not only between climate change and the overexploitation of nature and wildlife but also with global issues of precarious employment, poverty, food insecurity, and above all an array of inequalities in terms of health, gender, race, geography, income and urban access to green space. The need for interconnected solutions to these interrelated problems is inescapable. Governments and organisations need to adopt holistic plans in responding to the pandemic, and in 'building back better' once it is under control.

Youth and civil society movements have long called for all-encompassing approaches and 'systems change' to deal with the climate and biodiversity crises. Not only are these two linked but they cannot be solved without addressing social and economic issues. This has significant implications for climate- and nature-related policies and targets: for example, expanding protected areas and area-based conservation must take account of the voices, rights, knowledge and livelihoods of Indigenous and local communities.

Responding to COVID-19 demands a cross-sectoral and integrated way of seeing the global challenges. While it is disheartening that climate and nature action was somehow relegated to a supporting role in 2020, the pandemic has also been a source of focus, motivation and energy for young activists in the climate-nature space.

With important international gatherings scheduled for 2021, and as post-pandemic plans are drafted, young people strongly feel the responsibility to ensure that the climate-nature momentum is maintained. We need scalable solutions and systemic transformation towards a more just world based on ecological principles. Solidarity and cooperation are being built among young activists from diverse backgrounds working in previously siloed issues like biodiversity, climate, human rights, health and social justice.

Having been part of this hopeful and urgent work during 2020, I can attest that youth are ready for the decisions, conversations and challenges that 2021 will bring. The question now is whether world leaders are ready too: whether they will mirror - or overlook - the courage, collaborative spirit and boldness displayed by our tenacious generation.

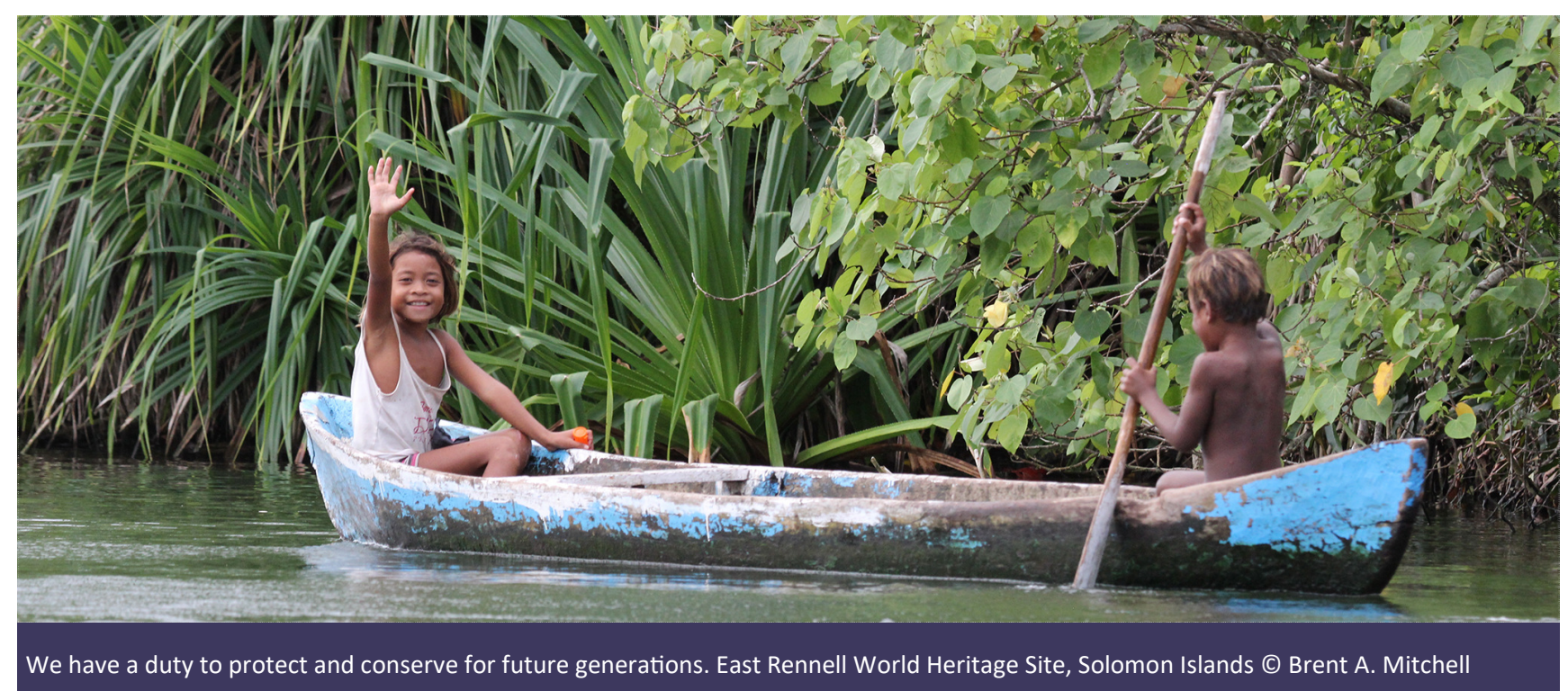


Phillips et al.

\section{RESUMEN}

Una docena de ensayos cortos en forma de reflexiones personales de un distinguido grupo de personas, a quienes se les pidió que consideraran las implicaciones más profundas de la pandemia y su importancia para la relación de la humanidad con la naturaleza. Entre los autores se encuentran expresidentes de dos países, dos galardonados con el Premio Nobel, dos expresidentes de la UICN, varias personalidades del mundo académico y líderes de convenios internacionales, ONG nacionales e internacionales, pueblos indígenas y representantes de la juventud mundial. Juntos, abarcan todos los aspectos del quehacer humano, desde la economía hasta la ética, y abordan el papel de la comunidad internacional, los gobiernos, la industria, la sociedad civil y los individuos.

\section{RÉSUMÉ}

Nous présentons une douzaine de courts essais sous forme de réflexions personnelles par des personnalités éminentes, dont les auteurs ont été invités à se pencher sur les implications plus profondes de la pandémie et son importance pour les relations de l'humanité avec la nature. Parmi les auteurs figurent d'anciens présidents de deux pays, deux lauréats du prix Nobel, deux anciens présidents de l'UICN, plusieurs universitaires de premier plan et des dirigeants de conventions internationales, d'ONG nationales et internationales, de peuples autochtones et de jeunes du monde entier. Ensemble, ils couvrent tous les aspects de l'activité humaine, de l'économie à l'éthique, et abordent les rôles de la communauté internationale, des gouvernements, de l'industrie, de la société civile et des individus. 